\title{
Relation of the Effect of Relative Age on Certain Anthropometric Characteristics of Adolescents
}

ISSN: 2577-1914

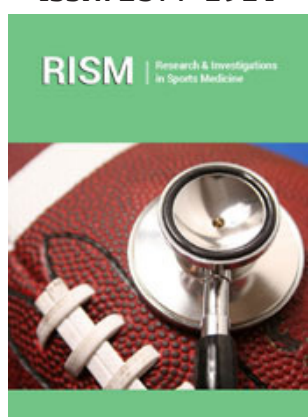

*Corresponding author: Obesity; Type II diabetes; Ischemic heart disease; Hypertensive diseases

Submission: 酒 March 10, 2020

Published: 眥September 17, 2020

Volume 7 - Issue 1

How to cite this article: Joksimović Marko*, Petković Emilija, Savić Vladan, et al. Relation of the Effect of Relative Age on Certain Anthropometric Characteristics of Adolescents. Res Inves Sports Med, 7(1): RISM.000652. 2020. DOI: $10.31031 /$ RISM.2020.07.000652

Copyright@ Joksimović Marko, This article is distributed under the terms of the Creative Commons Attribution 4.0 International License, which permits unrestricted use and redistribution provided that the original author and source are credited.
Joksimović Marko1*, Petković Emilija² ${ }^{2}$ Savić Vladan ${ }^{3}$, Lilić Ana², Nikšić Elvira ${ }^{4}$ Pantović Marko ${ }^{5}$ and Mušović Adnan 6

${ }^{1}$ Football Club National, Montenegro

${ }^{2}$ Faculty of Sport and Physical Education, University of Niš, Serbia

${ }^{3}$ Faculty of Sport and Physical Education, University of East Sarajevo, Bosnia and Herzegovina ${ }^{4}$ Faculty of Educational Sciences, University of Sarajevo, Bosnia and Herzegovina

${ }^{5}$ Independent Researcher, Serbia

${ }^{6}$ Elementary school Marko Miljanov, Montenegro

\begin{abstract}
Background: Studying the differences of relative age and relation to selected anthropometric parameters that occur in adolescents, it was concluded that other social, economic and psychological factors influence the phenomenon whose significance should be reduced.

Objective: The aim of the study was to determine how much adolescents differ in certain anthropometric characteristics in relation to the relative age effect (RAE).

Methods: The study included a sample of 73 students of the first grade of Miloje Dobrašinović High School in Bijelo Polje (Montenegro), divided into two sub-samples. The first sub-sample included 27 boys, while the second sub-sample included 46 girls divided into four groups according to RAE.

Results: Research results indicate that as many as $76.7 \%$ of children in the total sample are obese. Of these, $63 \%$ are girls and $13.7 \%$ boys who were born in April May and June, while the other boys $23.3 \%$ have normal nutritional values.

Conclusion: Adolescents are advised to exercise at least 60 minutes daily, with notion that they should be included in moderate or high-intensity aerobic physical activity, but also at least three times a week in high-intensity physical activity.
\end{abstract}

Keywords: Obesity; Type II diabetes; Ischemic heart disease; Hypertensive diseases

\section{Introduction}

Each independent state unit has in its education system the norms according to which children must have a certain maturity, measured by the number of years, in order to participate in the educational system. Thus, e.g. different education systems have adopted a law that a child becomes mature enough to go to school at the age of seven, and if a parent wants that a child starts at the age of six, he or she must undergo additional psychological and sociological checks to prove that the child is mature enough to be able to begin schooling. With this approach to the problem, there is a possibility of differences in the average level of maturity within each group. Such an initial effect of relative age difference (RAE) for children according to research $[1,2]$ should diminish or even overcome over time, although there are differences in children who have an innate ability to adjust more quickly in the midst and biological maturity [3-5]. The differences in chronological age between children in one age group is known as relative age and its significance as RAE. A great deal of scientific research provides information about RAE in the teaching process [6-9] as a possible cause of variation observed in the performance of children born in the same year $[9,10]$. Also, the existence of RAE has been studied as a secondary factor influencing the development of talents in sport and their ability to achieve top sporting outcomes [11]. 
The positive impact of physical activity is largely neglected today, although physical exercise affects all systems of the body: cardiovascular, respiratory, immune, musculoskeletal systems. The sedentary lifestyle has contributed to the energy intake of food being higher than energy consumption leading to weight gain and obesity. Overweight and obesity factors, according to Hajmer [12] represent a new global challenge for public health. According to a report by the World Health Organization (WHO), insufficient physical activity has been declared an independent risk factor and is a health problem for a nation. The trend of physical activity in developed countries is characterized by a lower degree of physical activity than ever before, and according to Trost et al. [13] 2/3 of the total population is physically inactive. In general, the level of physical activity decreases with age and this decline is particularly pronounced during adolescence [14-16]. A decrease in the level of physical activity in girls compared to boys was noticeable and slightly higher in adolescent girls [17].

The Body Mass Index (BMI) has been used to define the medical standard of obesity in many countries since the mid-1980s, and this method of assessment is used in WHO statistics [18]. An increase in the percentage of BF is observed after puberty when differences in the sex composition and topological composition of the body are visible. However, the dynamics of body composition are associated with the growth of children and may change due to the high prevalence of obesity in the younger population [19]. Previous studies have found that BMI is correlated with BF in children [20,21], $r=0.73$ in boys and $r=0.70$ in girls [22]. Body composition in children is extremely difficult to measure because precise techniques require a high degree of compliance and are available only to specialized research centers [23], however, Van Itallie \& Segal [24] found that bioelectric impedance analysis (BIA) can quickly and conveniently assess body fat (BF) levels in children and is a non-invasive tool for assessing BF in children.

Studying the differences of relative age and relation to selected anthropometric parameters that occur in adolescents, it was concluded that other social, economic, and psychological factors influence the phenomenon whose significance should be reduced [25]. To reduce negative RAE in athletes, a new categorization system based on either biological [26] or chronological age [2729] is proposed. Research relating to adolescents participating in sports clubs has led to the finding that the existence of RAE is more pronounced in athletes participating in a highly competitive novice [30] than at the recreational level [31,32]. Based on all of the above, the aim of the study was to determine how much adolescents differ in certain anthropometric characteristics relative to RAE.

\section{Methods}

\section{Participants}

The study included a sample of 73 students of the first grade of Miloje Dobrašinović High School from Bijelo Polje (Montenegro), divided into two sub-samples. The first sub-sample included 27 boys of average body height (Mean $182.05 \pm 5.66 \mathrm{~cm} \mathrm{Std.Dev.),} \mathrm{Body}$ weight (74.64 $\pm 13.31 \mathrm{~kg})$, BMI $\left(22.43 \pm 3.57 \mathrm{~kg} / \mathrm{m}^{2}\right)$, year $(15 \pm 0.5)$, and the second sub-sample 46 girls of average body height (164.3 $\pm 5.44 \mathrm{~cm})$, body weight $(63.47 \pm 11.64 \mathrm{~kg})$, BMI $(23.47 \pm 4.16 \mathrm{~kg} /$ $\mathrm{m}^{2}$ ), year $(15 \pm 0.5)$.

\section{Procedure}

The students were divided into four groups according to the relative age effect. The first group consisted of students born in January, February and March. The second group consisted of students born in April, May and June. The third group consisted of students born in July, August and September, while the fourth group consisted of students born in October, November and December. All anthropometric variables (Body Height, Body Weight, Body Fat and Body Mass Index) were measured according to the standard procedures of the International Society for the Advancement of Kinanthropometry (ISAK) by Marfell-Jones et al. [33]. Body height (BH) was measured with an anthropometer, while body weight (BW), body fat percentage (BF) and body mass index (BMI) were measured with Tanita BC-545N bioelectrical impedance analyzer (https://tanita.eu/tanita-bc-545n). The research was carried out in the physical education hall of the Miloje Dobrašinović gymnasium, in the school year 2018/19. from 08:00 am to 10:00 am. The study was approved by the Ethics Committee of the Faculty of Sport and Physical Education, University of Niš, in accordance with the Declaration of Helsinki [34]. The study was supported by all parents, who gave their written consent. The research was non-invasive in nature, held in the hall of the gymnasium in Bjelo Polje. The conditions in the sports hall met the optimal criteria for humidity and light.

\section{Data analyses}

All data collected through the survey were processed by comparative statistics. From the space of comparative statistics, the discriminant parametric procedure multiple analysis of variance MANOVA and Post Hoc was used to determine differences with respect to the effect of relative age, while Pearson's correlation coefficient ( $\mathrm{r}$ ) was used to determine the correlation. The statistical program for personal computers SPSS for Windows version 20.0 was used for data processing.

\section{Results}

Looking at Table 1, the results of the MANOVA test indicate that there is a statistically significant difference $(p=.000)$. It can be concluded that boys and girls differ in anthropometric characteristics with respect to RAE. The analysis of Post Hoc results (Table 2) shows the differences in anthropometric characteristics between boys and girls relative to RAE, while Table 3 shows the correlation between BF and BMI. Figure 1 shows the percentile BMI values of boys and girls relative to RAE.

Table 1: Multivariate Analysis of Variance (MANOVA).

\begin{tabular}{|c|c|c|c|c|}
\hline & Value & F & Sig. & $\begin{array}{c}\text { Partial eta } \\
\text { Squared }\end{array}$ \\
\hline $\begin{array}{c}\text { Wilkis` } \\
\text { Lambda }\end{array}$ & 0.108 & 3.405 & 0 & 0.272 \\
\hline
\end{tabular}


Table 2: Legend: BH: Boys $1^{\text {st }}$ vs Girls $1^{\text {st }}, 2^{\text {nd }}, 3^{\text {rd }}$ and $4^{\text {th }} p<.000 \dagger$; Boys $2^{\text {nd }}$ vs Girls $1^{\text {st }}, 2^{\text {nd }}, 3^{\text {rd }}$ and $4^{\text {th }} p<.000 \neq ;$ Boys $3^{\text {rd }}$ vs Girls $1^{\text {st }}, 2^{\text {nd }}, 3^{\text {rd }}$, and $4^{\text {th }} \mathrm{p}<.000$ †; Boys $4^{\text {th }}$ vs Girls $1^{\text {st }}, 2^{\text {nd }}, 3^{\text {rd }}$ and $4^{\text {th }} \mathrm{p}<.000$ ‡. BW: Boys $3^{\text {rd }}$ vs Boys $1^{\text {st }} p<.05$ ৩; Boys $2^{\text {nd }}$ vs Girls $2^{\text {nd }} p<.004,3^{\text {rd }}$ and $4^{\text {th }} p<.05$ $\neq$; Boys $3^{\text {rd }}$ vs Girls $2^{\text {nd }} p<.000,3^{\text {rd }}$ and $4^{\text {th }} p<.002$ †. BF: Boys $1^{\text {st }}$ vs Girls $1^{\text {st }} p<.001,2^{\text {nd }} p<.002,3^{\text {rd }}$ and $4^{\text {th }} p<.000$ †, Boys $3^{\text {rd }} p<.002^{\circ} ;$ Boys $2^{\text {nd }}$ vs Girls $1^{\text {st }} \mathrm{p}<.012,3^{\text {rd }} \mathrm{p}<.008,4^{\text {th }} \mathrm{p}<.003 \neq$, Boys $3^{\text {rd }} \mathrm{p}<.05$; Boys $3^{\text {rd }}$ vs Boys $4^{\text {th }} \mathrm{p}<.006<$; Boys $4^{\text {th }}$ vs Girls $1^{\text {st }} \mathrm{p}<.003,2^{\text {nd }} \mathrm{p}<.013,3^{\text {rd }} \mathrm{p}<.002$, and $4^{\text {th }} \mathrm{p}<.001 \neq$. BMI: Boys $3^{\text {rd }}$ vs Boys $1^{\text {st }} \mathrm{p}<.05 \diamond$.

\begin{tabular}{|c|c|c|c|c|c|c|c|c|}
\hline \multirow[t]{2}{*}{ Variables } & \multicolumn{2}{|c|}{$1^{\text {st }}$ Group } & \multicolumn{2}{|c|}{$2^{\text {nd }}$ Group } & \multicolumn{2}{|c|}{$3^{\text {rd }}$ Group } & \multicolumn{2}{|c|}{$4^{\text {th }}$ Group } \\
\hline & Boys & Girls & Boys & Girls & Boys & Girls & Boys & Girls \\
\hline $\mathrm{BH}(\mathrm{cm})$ & $178.14 \pm 6.706 \dagger$ & $165.92 \pm 5.219$ & $183.16 \pm 7.341 \neq$ & $164.25 \pm 6.892$ & $180.57 \pm 6.321 \dagger$ & $165.54 \pm 5.517$ & $186.33 \pm 2.309 \ddagger$ & $161.55 \pm 4.165$ \\
\hline BW (kg) & $65.72 \pm 10.848$ & $68.43 \pm 19.277$ & $75.51 \pm 13.356 \neq$ & $60.48 \pm 8.543$ & $81.95 \pm 20.9510, \dagger$ & $62.91 \pm 11.433$ & $75.38 \pm 8.094$ & $62.06 \pm 7.323$ \\
\hline $\mathrm{BF}(\%)$ & $24.08 \pm 6.126 \dagger, \diamond$ & $34.90 \pm 7.581$ & $27.70 \pm 4.654 \ddagger,>$ & $31.62 \pm 3.902$ & $33.41 \pm 6.799$ < & $33.89 \pm 6.025$ & $22.93 \pm 6.426 \neq$ & $34.93 \pm 3.955$ \\
\hline $\begin{array}{c}\text { BMI (kg/ } \\
\left.\mathrm{m}^{2}\right)\end{array}$ & $20.65 \pm 3.249$ & $24.61 \pm 6.134$ & $22.43 \pm 3.464$ & $22.47 \pm 3.387$ & $24.96 \pm 5.215 \diamond$ & $22.97 \pm 4.347$ & $21.71 \pm 2.357$ & $23.83 \pm 2.791$ \\
\hline
\end{tabular}

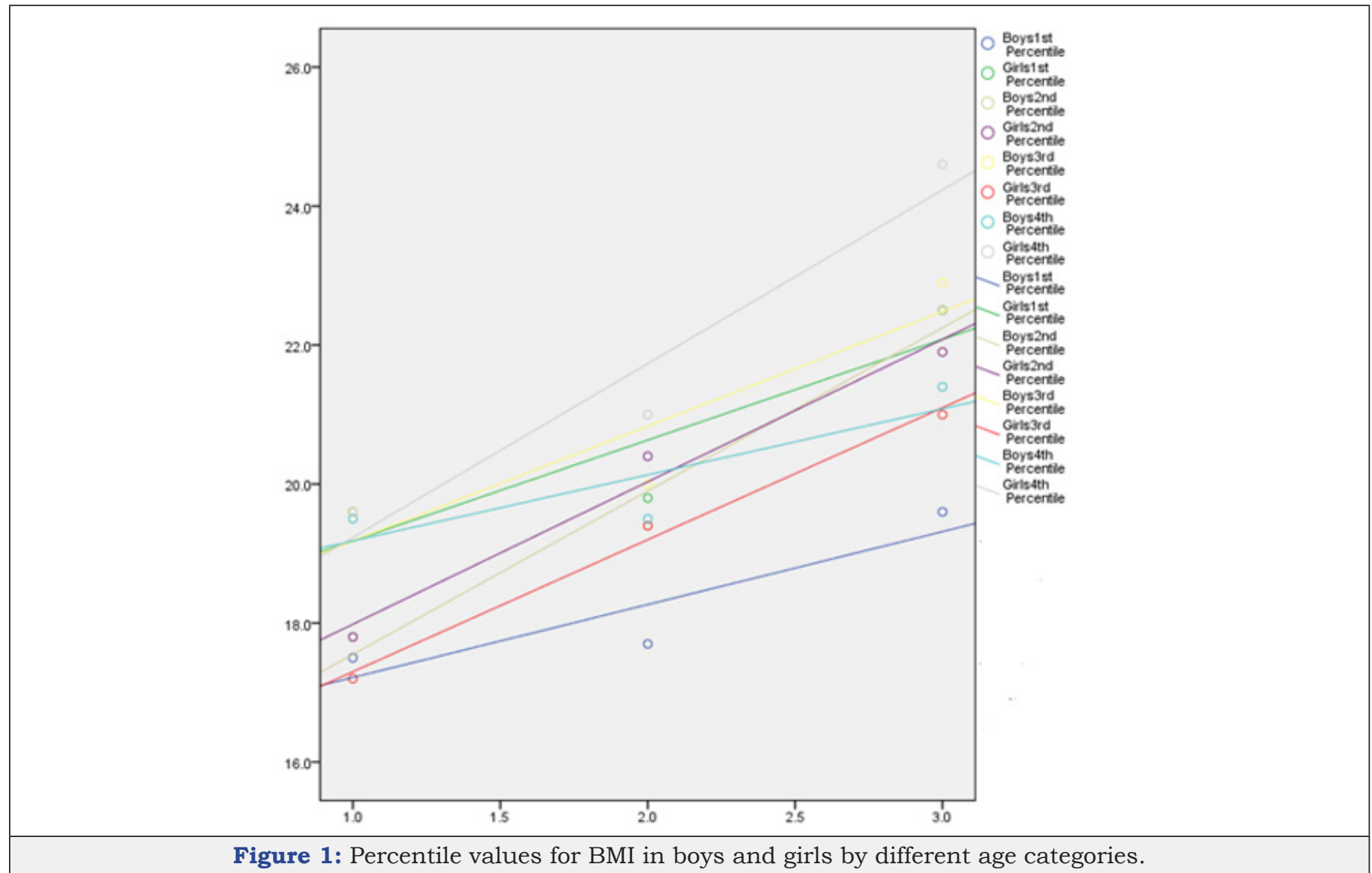

Table 3: Correlation between BF and BMI.

\begin{tabular}{|c|c|c|c|}
\hline Group $/$ sex & Variables & BF & BMI \\
\hline \multirow{2}{*}{$1^{\text {st }} /$ Female } & $\mathrm{BF}$ & 1 & $.941^{* *}$ \\
\cline { 2 - 4 } & $\mathrm{BMI}$ & & 1 \\
\hline \multirow{2}{*}{$3^{\text {rd }} /$ Female } & $\mathrm{BF}$ & 1 & $.883^{* *}$ \\
\cline { 2 - 4 } & $\mathrm{BMI}$ & & 1 \\
\hline \multirow{2}{*}{$4^{\text {th }} /$ Female } & $\mathrm{BF}$ & 1 & $.723^{*}$ \\
\cline { 2 - 4 } & $\mathrm{BMI}$ & & 1 \\
\hline
\end{tabular}

\section{Discussion}

The aim of the study was to determine how much adolescents differ in anthropometric characteristicsin relation to RAE. Measuring the anthropometric characteristics of the human body, processing and studying the data obtained are an integral part of a series of basic applied research in the field of physical education and sport [35]. Through the realization of transversal research, i.e. A single measurement of a larger number of subjects in a given population gives insight into the average state of physical development [36]. Analyzing the $\mathrm{BH}$ results in Table 2, it is noticeable that boys in all groups had higher $\mathrm{BH}$ values than girls in all groups. In terms of BW, boys in group 3 had higher body weight than boys in group 1 ( $p$ $=.05$ ). Also, boys in group 3 had higher BW values than girls in $2^{\text {nd }}$ $(\mathrm{p}=.000), 3^{\text {rd }}$ and $4^{\text {th }}$ groups $(\mathrm{p}<.002)$, while boys in group 2 had higher BW values than girls from $2^{\text {nd }}(p=.004), 3^{\text {rd }}$ and $4^{\text {th }}$ groups $(p=.05)$. Higher body height values in boys compared to girls can be explained by the fact that during periods of rapid adolescent development, the lower extremities of boys grow relatively faster 
than in girls [37]. During adolescence, about $40 \%$ of bone mass is obtained, making the puberty phase an optimal time to accumulate bone mass and reduce the risk of fractures. Minimal differences in bone mass between the sexes exist in the pre-pubertal period, while significant differences occur during puberty, when bone growth is influenced by sex hormones.

Estrogen limits periosteal bone expansion but promotes endocortical contraction, while androgenic hormones stimulate periosteal bone apstration, resulting in boys having wider bones, greater corticos thickness, and wider medullary cavities than girls [38]. Growth hormone (GH) secretion is suppressed in children with high BMI [39]. GH decreases in obese individuals, and peak GH levels are lower in obese children than in normal-weight children [40], also, GH in obese children with high BMI levels may result from decreased production and secretion of GH [41,42]. Research indicates that it is known that at any age, the average body height of girls is closer to the height they reach at adulthood than is the case for boys. As early as the third year of life, girls reach half the total height they will reach at adulthood, and boys reach at three and a half years of age [37]. On average, girls with fast acceleration, at 10.7 years of age, reach a peak in body weight unlike boys who achieve this at 12.6 years. Girls who matured at the expected rate were 12.1 years old and boys 14.0 years old at the time of peak body mass $[37,43]$. All these are benchmarking that gender differences are evident and have a corresponding upward trend, as confirmed in the study [44]. Also, the results of the current research are in line with the research of Šegregur et al. [45] which showed significant differences in the BH and BW between girls and boys. Similar results to the current study were obtained by Nakata et al. [46] where they recorded significant RAE in boys aged 7 to 15 years in anthropometric characteristics, whereas in girls they did not record statistical significance in RAE.

Hook et al. [17] state that a decline in physical activity in adolescence is noticeably observed in girls. This is also confirmed by our results where girls had higher BF and BMI values than boys (Table 2). Also, BMI is used worldwide to classify people as malnourished, normal and obese [47]. Early detection of overweight and obesity in children is usually based on the use of Body Mass Indexs, due to its simplicity and relatively large association with BF [48-50]. The correlation between BMI and BF was observed in girls from the $1^{\text {st }}$ group $(\mathrm{r}=.941), 3^{\text {rd }}$ group $(\mathrm{r}=.883)$ and $4^{\text {th }}$ group $(\mathrm{r}=$ .723), while the association between BMI and BF was not observed in boys. Similar results were obtained by Maynard et al. [20], Roche et al. [21], Skrzypzak et al. [51], Amini [52], Centers for Disease Control and Prevention (CDC) set thresholds for BMI in percentiles where children with percentiles $\left(85^{\text {th }}-94^{\text {th }}\right)$ are classified as overweight, while children with percentiles $\left(\geq 95^{\text {th }}\right)$ are classified as obese [53]. In our study, boys in the $1^{\text {st }}, 3^{\text {rd }}$, and $4^{\text {th }}$ groups had a BMI $\left(<85^{\text {th }}\right.$ percentile $)$, while boys in the $2^{\text {nd }}$ as well as girls in all four groups had a BMI ( $>95^{\text {th }}$ percentile). Freedman et al. [54] state that children with a BMI of the $\left(85^{\text {th }}-94^{\text {th }}\right.$ percentile $)$ have high levels of BF, which was confirmed in this study. Ogden, et al. [55] state that in the USA, $17 \%$ of children have a BMI ( $>95^{\text {th }}$ percentile), while $16 \%$ have a BMI of $\left(85^{\text {th }}-94^{\text {th }}\right.$ percentile). Ayers \& Sariscsany [56] recommend reference intervals of physiological BF values in percentages for boys aged 15 years (20.1\%) and girls (29.1\%). Comparing the average values of BF of boys and girls (Table 2), it is noticeable that their values exceed the stated standards.

Insufficient physical activity during adolescence can have long-term effects on the health of an individual in adulthood as a consequence of chronic illness and a sedentary lifestyle [57]. Studies have shown Guo et al. [58] correlation of overweight in adolescence and overweight in adulthood, where overweight and obesity are responsible for $80 \%$ of type II diabetes, $35 \%$ of ischemic heart disease, and 55\% of hypertensive diseases in adults [59]. Based on all of the above, adolescents are advised to exercise at least 60 minutes daily for physical activity, noting that they spend most of their time at moderate or high intensity aerobic physical activity, but also at least three times per week for high intensity physical activity. Bone and muscle strengthening exercises are recommended during this period, which should be included as part of a 60-minute recommended workout three times a week $[60,61]$.

\section{Conclusion}

The results of the current study on a sample of 73 students of both sexes, chronologically aged (15 \pm 0.5 years) confirmed differences between boys and girls in anthropometric characteristics with respect to RAE. Boys had higher BH and BW, while girls had higher BMI and BF values. Such results are expected if one takes into account the trend of growth and development of certain characteristics and their acceleration and deceleration. What is discouraging is that as many as $76.7 \%$ of children in the total sample are obese. Of these, $63 \%$ are girls and $13.7 \%$ boys who were born in April May and June, while the other boys 23.3\% have normal nutritional values. The results of the research are more than alarming, so it is necessary to adjust the curriculum to regulate body fat relative to ERS. The main factor contributing to these indicators is today's lifestyles of children and young people, as today's development is moving towards the advancement of technology, however, the work performance and involvement of children in physical activities are minimized. Much research is needed to understand the negative impact of obesity on students 'anthropological status and to express physical activity as an imperative that builds a healthy environment and population [62].

\section{Limitations and Strength of the Study}

In some further studies, certain parameters of relative age and obesity need to be complemented by external factors affecting quality of life (preferably through a questionnaire on nutritional habits or physical activity of children) to complement the results of this study.

\section{Acknowledgements}

This study is a part of the project OI 179024 funded by the Ministry of Educational, Science and Technological Development of the Republic of Serbia. 


\section{References}

1. Helsen WF, Starkes JL, Van Winckel J (2000) Effect of a change in selection year on success in male soccer players. Am J Hum Biol 12(6): 729-735.

2. Carling C, Le Gall F, Reilly T, Williams AM (2008) Do anthropometric and fitness characteristics vary according to birth date distribution in elite youth academy soccer players? Scand J Med Sci Sports 19(1): 3-9.

3. Fredriksson P, Öckert B (2005) Is early learning really more productive? the effect of school starting age on school and labor market performance. IZA Institute of Labor Economics 124: 977-1004.

4. Bedard K, Dhuey E (2006) The persistence of early childhood maturity: international evidence of long-run age effects. The Quarterly Journal of Economics 121(4): 1437-1472.

5. Datar A (2006) Does Delaying Kindergarten Entrance Give Children a Head Start? Economics of Education Review 25(1): 43-62.

6. Bell JF, Massey A, Dexter T (1997) Birthdate and ratings of sporting achievement: analysis of physical education GCSE Results. European Journal of Physical Education 2(2): 160-166.

7. Musch J, Grondin S (2001) Unequal competition as an impediment to personal development: a review of the relative age effect in sport. Developmental Review 21(2): 147-167.

8. Strøm B (2004) Student achievement and birthday effects. Citeseer, pp. $1-21$.

9. Diaz Del Campo DG, Vicedo JCP, Vilora SG, Jordan ORC (2010) The relative age effect in youth soccer players from Spain. Journal of Sports Science and Medicine 9(2): 190-98.

10. Barnsley RH, Thompson AH, Legault P (1992) Family planning: Football style. The relative age effect in football. International Review for the Sociology of Sport 27(1): 77-87.

11. Baker J, Horton S (2004) A review of primary and secondary influences on sport expertise. High Ability Studies 15(2): 211-228.

12. Hajmer S (2010) Physical activity and health in Europe. Faculty of Kinesiology, Zagreb, Croatia.

13. Trost SG, Owen N, Bauman AE, Sallis JF, Brown W (2002) Correlates of adults 'participation in physical activity: review and update. Medicine \& Science in Sports \& Exercise 34(12): 1996-2001.

14. Kemper H, Twisk J, Koppes L, Van Mechelen W, Bertheke Post G (2001) A 15-year physical activity pattern is positively related to aerobic fitness in young males and females (13-27 years). European Journal of Applied Physiology 84(4): 395-402.

15. Kimm S, Glynn N, Kriska A, Barton B, Kronseberg S, et al. (2002) Decline in physical activity in black girls and white girls during adolescence. New England Journal of Medicine 347(10): 709-715.

16. Nader PR, Bradley RH, Houts RM, McRitchie SL, O Brien M (2008) Moderate-to-vigorous physical activity from ages 9 to 15 years. Journal of American Medical Association 300(3): 295-395.

17. Hook MB, Plasqui G, Gerver Wj M, Westerterp KP (2003) Physical activity level measured by double labeled water and accelerometry in children. European Journal of Applied Physiology 89(6): 624-626.

18. Pavlović R, Mihajlović I, Idrizović K, Vrcić M, Stanković D, et al. (2018) Differences in anthropometric traits and trend of change in high school students. Int J Sport Stud Hlth 1(1): 1-5.

19. Santos LP, Santos IS, Matijasevich A, Barros AJD (2019) Changes in overall and regional body fatness from childhood to early adolescence. Scientific Reports 9: 1-7.

20. Maynard LM, Wisemandle W, Roche AF, Chumlea WC, Guo SS, et al. (2001) Childhood body composition in relation to body mass index. Pediatrics 107(2): 344-350.
21. Roche AF, Sievogel RM, Chumlea WC, Webb P (1981) Grading body fatness from limited anthropometric data. Am J Clin Nutr 34(12): 28312838.

22. Rao KM, Arlappa N, Radhika MS, BalaKrishna N, Laxmaiah A, et al. (2012) Correlation of fat mass index and fat-free mass index with percentage body fat and their association with hypertension among urban South Indian adult men and women. Ann Hum Biol 39(1): 54-58.

23. Nakao T, Komiya S (2003) Reference norms for a fat-free mass index and fat mass index in the japanese child population. J Physiol Anthropol Appl Human Sci 22(6): 293-298.

24.Van Itallie TB, Segal KR (1989) Nutritional assessment of hospital patients: new methods and new opportunities. Am J Hum Biol 1: 205208.

25. Delorme N, Boiché J, Raspaud M (2010) Relative age effect in elite sports: methodological bias or real discrimination? European Journal of Sport Science 10(2): 91-96.

26. Baxter Jones A (1995) Growth and development of young athletes. Should competition levels be age related? Sports Medicine 20(2): 59-64.

27. Boucher J, Halliwell W (1991) The Novem System: A practical solution to age grouping. CAHPER Journal 57(1): 16-20.

28. Hurley W, Lior D, Tracze S (2001) A proposal to reduce the age discrimination in Canadian minor ice hockey. Canadian Public Policy 27(1): 65-75.

29. Hurley W (2009) Equitable birthdate categorization systems for organized minor sports competition. European Journal of Operational Research 192(1): 253-264.

30. Cobley S, Baker J, Wattie N, McKenna J (2009) Annual age-grouping and athlete development: a meta-analytical review of relative age effects in sport. Sports Med 39(3): 235-256.

31. Barnsley RH, Thompson AH (1988) Birthdate and success in minor hockey: the key to the NHL. Can J Behav Sci 20: 167-176.

32. Hancock DJ, Ste-Marie DM, Young BW (2013) Coach selections and the relative age effect in male youth ice hockey. Res Q Exerc Sport 84(1): 126-130.

33. Marfell-Jones M, Olds T, Stew A, Carter L (2006) International standards for anthropometric assessment. The International Society for the Advancement of Kinanthropometry, Australia.

34. World Medical Association (2013) World Medical Association declaration of helsinki ethical principles for medical research involving human subjects. JAMA 310(20): 2191-2194.

35. Jakonić D (2003) Osnove sportske medicine. Faculty of Physical Education, Novi Sad, Serbia.

36. Hedley AA, Ogden CL, Johnson CL, Carroll MD, Curtin LR, et al. (2004) Prevalence of overweight and obesity among US children, adolescents, and adults, 1999-2002. JAMA 291(23): 2847-2850

37. Abernethy B, Hanrahan JS, Kipers V, Mackinnon TL, Pandy GM, et al. (2013) Biofizičke Osnove Ljudskog Pokreta. In: Data Status, Human Kinetics, UK, pp. 1-408.

38. Magan A, Nyati NL, Micklesfieled KL, Norris AS, Pettifor MJ (2017) Metacarpal growth during adolescence in a longitudinal south african cohort. Journal of Bone and Mineral Research 32(12): 2355-2366.

39. Rose SR, Municchi G, Barnes KM, Kamp GA, Uriarte MM, et al. (1991) Spontaneous growth hormone secretion increases during puberty in normal girls and boys. J Clin Endocrinol Metab 73(2): 428-435.

40. Loche S, Cambiaso P, Carta D, Setzu S, Imbimbo BP, et al. (1995) The growth hormone-releasing activity of hexarelin, a new synthetic hexapeptide, in short normal and obese children and in hypopituitary subjects. J Clin Endocrinol Metab 80(2): 674-678. 
41. Veldhuis JD, Iranmanesh A, Ho KK, Waters MJ, Johnson ML, et al. (1991) Dual defects in pulsatile growth hormone secretion and clearance subserve the hyposomatotropism of obesity in man. J Clin Endocrinol Metab 72(1): 51-59.

42. Lee J, Yoon J, Kang JM, Lee AY, Lee YS, et al. (2013) Influence of body mass index on the growth hormone response to provocative testing in short children without growth hormone deficiency. J Korean Med Sci 28(9): 1351-1355.

43. Hagg U, Taranger J (1991) Height and height velocity in early, average, and late maturers followed to the age of 25: A prospective longitudinal study of Swedishurban children from birth to adulthood. Ann Hum Biol 18(1): 47-56.

44. Koziel S, Gomula A (2017) Variation of height and BMI within school classes in 14-year-old children. Anthropol Anz 74(1): 77-80.

45. Šegregur D, Kuhar V, Parađzik P (2010) Antropometrical, motorical and functional abilites of first-grade secondary school students. Hrvatski Športskomedicinski Vjesnik 25: 67-74.

46. Nakata H, Akido M, Naruse K, Fujiwara M (2017) Relative age effect in physical fitness among elementary and junior high school students. Perceptual and Motor Skills 124(5): 900-911.

47. Nikolaidis PT (2012) Association between body mass index, body fat, per cent and muscle power output in soccer players. Central European Journal of Medicine 7(6): 783-789.

48. Krebs NF, Himes JH, Jacobson D, Nicklas TA, Guilday P, et al. (2007) Assessment of child and adolescent overweight and obesity. Pediatrics 4: S193-S228.

49. Rolland-Cachera MF (2011) Childhood obesity: current definitions and recommendations for their use. Int J Pediatr Obes. 6(5-6): 325-331.

50. Stupnicki R, Tomaszewski P, Midle K (2013) Body Mass Index-proposed norms for children and youths. Anthropology. 22: 203-213.

51. Skrzypozak M, Szerd A, Polanski-camera R, Skrzypules (2007) Assessment of the BMI, WHR and W/hit with pre and women. Anthropology 70: 3-13.
52. Amini R (2007) Comparison between bioelectrical impedance analysis and body mass index methods of determination of obesity prevalence in Ahvaz women. Eur J Clin Nutr 1(4): 478-482.

53. Barlow SE (2007) Expert Committee. Expert committee recommendations regarding the prevention, assessment, and treatment of child and adolescent overweight and obesity: summary report. Pediatrics 120 (4): 164-192.

54. Freedman D, Wang J, Thornton CJ, Mei Z, Sopher A, et al. (2009) classification of body fatness by body mass index-for age categories among children. Arch Pediatr Adolesc Med 163(9): 805-811.

55. Ogden CL, Carroll MD, Flegal KM (2008) High body mass index for age among US children and adolescents, 2003-2006. JAMA 299(20): 24012405.

56. Ayers FS, Sariscsany J (2013) The physical education for lifelong fitness: The physical best teacher's guide. $3^{\text {rd }}(\mathrm{edn})$, Human Kinetics Inc, UK, pp. $1-352$.

57. US Department of Health and Human Services (USDHHS) (2000a) Healthy people: understanding and improving health. Washington, DC, US.

58. Guo SS, Roche AF, Chumlea WC, Gardner JD, Siervogel RM (1994) The predictive value of childhood BMI values for overweight at age $34 \mathrm{y}$. American Journal of Clinical Nutrition 59(4): 1810-1819.

59. Tsigos C, Hainer V, Basdevant A, Finer N, Fried M, et al. (2008) Management of obesity in adults: european clinical practice guidelines. The European Journal of Obesity 1(2): 106-116.

60.WHO-World Health Organisation (1997a) Obesity-preventing and managing the global epidemic. Report of WHO consultation on obesity. Geneva, pp. 7-17.

61. (2008) Physical activity guidelines advisory committee report. U.S. Department of Health and Human Services, Washington, DC, USA, pp. 1-76.

62. (1997) The relationship between chronological age at kindergarten entrance and social skills development. USA. 